\title{
Instability of Natural Remanent Magnetism of Rocks
}

\author{
By N. KAWAI \\ Geological Institute, Kyoto University
}

Geological evidence and experimental results have given sufficient confirmation for the fact that the natural remanent magnetic polarization of rock (abb: N.R.M.) is not always stable throughout the geological time, but by the renewed application of the geomagnetic force upon the specimen, the direction is changed even within a short period. The manner in which the change proceeds with time has closely been watched since these several years. The results illustrated in the Fig. 1 and

The time-change of N.R.M. of rocks.

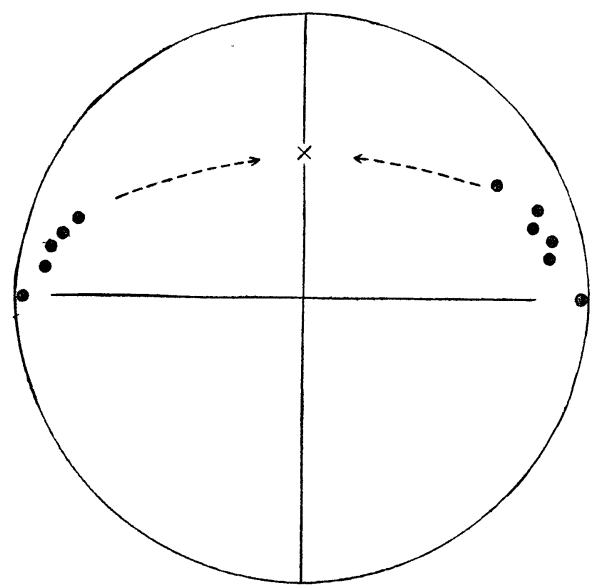

Fig. 1

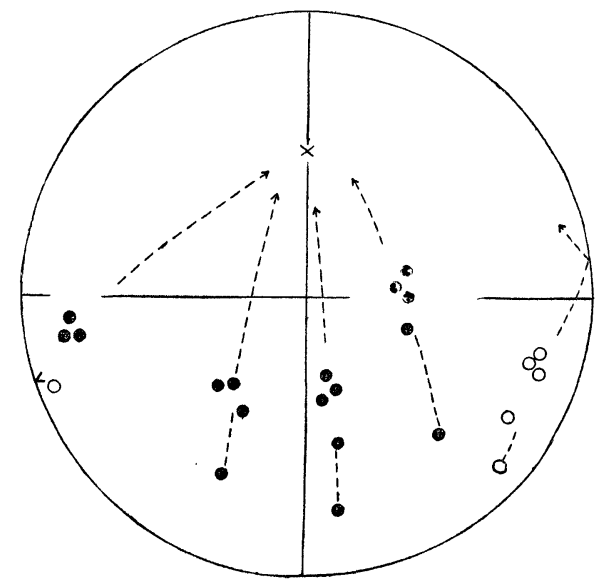

Fig. 2

- positive pole on lower hemi-sphere

positive pole on upper hemi-sphere

$\times$ present geomagnetic field

Fig. 2 are those of the typical time-changes of N.R.M. of rocks, which soon after the sampling have been kept in laboratory with fixed orientation, the geomagnetic field being applied to the specimen in the direction nearly perpendicular to that of the original N.R.M. in situ. The changes, in most cases, have taken place in such a manner that the direction of remanent polarity tends to approach towards the magnetic field.

The stability and instability tests of rocks through the geological time up to the present were put into practice as follows. Many pieces of pebbles in conglomerate were sampled and the directions of their N.R.M. were measured. The polarity is estimated to be stable when these pebbles have retained the random directions of N.R.M. with which the pebbles had been put into the stratum. Whereas, it is concluded to be meta-stable when the direction of the N.R.M. of the pebbles have followed, or at 
Table I-A Igneous Rock

\begin{tabular}{|c|c|c|c|c|}
\hline $\begin{array}{l}\text { Rock } \\
\text { name }\end{array}$ & Locality & $\begin{array}{l}\text { Direction } \\
\text { of N.R.M. }\end{array}$ & Stability & Age \\
\hline Andesite & Nara & Normal & meta-stable & \\
\hline Dolerite & Nara & NE72 ${ }^{\circ}$ & & lower \\
\hline dyke & & $\operatorname{dip} 32^{\circ}$ & stable & Plio. \\
\hline Andesite & Kyoto & Normal & unstable & \\
\hline Andesite & Kyoto & Reverse & meta-stable & \\
\hline Basalt & Hyogo & Reverse & stable & \\
\hline Basalt & Hyogo & Normal & meta-stable & \\
\hline Andesite & Hyogo & Normal & meta-stable & \\
\hline Andesite & Aomori & Reverse & stable & \\
\hline Basalt & Toyama & Reverse & & \\
\hline Andesite & Osaka & Reverse & stable & \\
\hline Andesite & Osaka & Reverse & meta-stable & \\
\hline Andesite & Osaka & Reverse & meta-stable & \\
\hline Basalt & Osaka & Reverse & meta-stable & Plio. \\
\hline Dacite & Osaka & Reverse & meta-stable & Plio. \\
\hline Sanukite & Osaka & Normal & stable & Plio. \\
\hline Andesite & Osaka & Normal & meta-stable & Plio. \\
\hline Andesite & Osaka & Normal & meta-stable & Plio. \\
\hline $\begin{array}{l}\text { Pitch } \\
\text { stone }\end{array}$ & Osaka & Normal & meta-stable & Plio. \\
\hline Dacite & Nara & Reverse & stable & Mio. \\
\hline Andesite & Nara & Reverse & stable & Mio. \\
\hline
\end{tabular}

Table I-B Sedimentary Rock

\begin{tabular}{|c|c|c|c|c|}
\hline $\begin{array}{l}\text { Rock } \\
\text { name }\end{array}$ & Locality & $\begin{array}{l}\text { Direction } \\
\text { of N.R.M. }\end{array}$ & Stability & Age \\
\hline $\begin{array}{l}\text { Ordinary } \\
\text { Sediment }\end{array}$ & Boso & Normal & unstable & Pleisto. \\
\hline Sand & Boso & Normal & unstable & Pleisto. \\
\hline Clay & Boso & Normal & unstable & Pleisto. \\
\hline Clay & Osaka & Normal & unstable & Lower \\
\hline Azuki tuff & Osaka & Reverse & meta-stable & Pleisto. \\
\hline Clay & Osaka & Normal & unstable & Pleisto. \\
\hline $\begin{array}{l}\text { Ordinal } \\
\text { Sediment }\end{array}$ & Boso & Normal & unstable & Plio. \\
\hline ,, & Boso & Normal & unstable & Plio. \\
\hline , & Boso & Normal & unstable & Plio. \\
\hline ," & Boso & Normal & unstable & Plio. \\
\hline ,' & Boso & Normal & unstable & Plio. \\
\hline ," & Boso & Normal & unstable & Plio. \\
\hline , & Boso & Normal & unstable & Plio. \\
\hline $\begin{array}{r}\text { Tuffacious } \\
\text { Sediment }\end{array}$ & Boso & Reverse & meta-stable & Lower \\
\hline Clay & Boso & Normal & unstable & Plio. \\
\hline $\begin{array}{l}\text { Volcanic } \\
\text { Sediment }\end{array}$ & Boso & Reverse & meta-stable & Mio. \\
\hline Shale & Boso & Normal & meta-stable & Mio. \\
\hline Shale & Boso & Normal & unstable & Mio. \\
\hline Sand & Boso & Normal & unstable & Mio. \\
\hline
\end{tabular}

least have had a tendency to follow, that of the geomagnetic field. However, when we could detect any appreciable change in the direction of N.R.M. by the repeated measurements in laboratory, it is concluded to be unstable. Thus the igneous and sedimentary rocks hitherto observed by us are classified into three kinds of groups, namely, stable class, meta-stable class and unstable class, the locality and the observed data of N.R.M., are tabulated in Table I with special reference to the above mentioned stability.

It should be noticed that the major part of the tertiary sediments reveals to be unstable except several volcanic sediments with reverse N.R.M. e.g. Azuki tuff in Ôsaka basin (Lower Pleistocene), tuffacious sediments in Bôsô basin (Lower Pliocene) $e t c$. On the other hand, greater part of eruptive rocks is classified either to stable or meta-stable class and the N.R.M. is considered to be better in stability as compared to that of the sediments. Several unstable cases aside, the data of eruptive rocks are in favour of interpretating the geomagnetic history. 